\title{
The Role of Media and Social Movement in Human Rights Issue: The Case of 'Comfort Women' by Japan Colonization
}

\author{
Anna C. Suwardi \\ Naresuan University \\ Atina Rosydiana \\ The Dialogue, Emphatic Engagement and Peacebuilding (DEEP) Network
}

\begin{abstract}
Many countries in Asia were conquered by Japan during the World War II, including Korea and Indonesia. Romusha, or slavery system introduced by Japan, also imposed to women. Girls were sent to brothels as Jugun Ianfu/'comfort women'. Differ from men, women got double burdens, both physically and mentally, thus trauma was inevitable. The belief of taboo is also spreading, hence the movement of victims which demands to get their dignity back is rarely found. Using setting agenda theory and social movement theory, this paper argues that the best potential to promote human rights and justice of 'comfort women' goes to media. In South Korea, social movement has been advocating people about 'comfort women' as forced victims, not a voluntarily choice. Through engaging media, they hope to use its power to persuade people, changing the paradigm that 'comfort women' were not sexual workers, but victims of war who needs assistance from society to heal their trauma.
\end{abstract}

Keywords: 'comfort women', Japan colonization, media, sexual harassment, social movement

\begin{abstract}
Abstrak
Banyak negara di Asia merupakan korban Kolonisasi Jepang selama Perang Dunia II, termasuk Korea dan Indonesia. Romusha, sistem perbudakan Jepang juga dibebankan kepada perempuan. Remaja perempuan kala itu dikirim ke rumah prostitusi dan dijadikan Jugun Ianful comfort women/wanita penghibur. Sedikit berbeda dengan laki-laki, perempuan memperoleh beban ganda, baik fisik dan mental, sehingga trauma pun tak terelakkan. Pendapat tentang tabu beredar, namun jarang sekali ditemukan perjuangan korban untuk sekedar memulihkan nama baik mereka. Menggunakan teori agenda seting dan teori gerakan sosial, tulisan ini berargumen bahwa upaya potensial dalam mempromosikan hak asasi dan keadilan atas 'comfort women' adalah melalui media. Di Korea Selatan, gerakan sosial telah bekerjasama dengan media mengadvokasi masyarakat bahwa 'comfort women' adalah korban kekerasan dan bukan bersifat sukarela. Dengan mengajak serta media, diharapkan dapat memberikan kekuatan untuk menyakinkan masyarakat dan merubah paradigma bahwa 'comfort women' bukanlah pekerja seksual, melainkan korban kekejaman di zaman perang yang membutuhkan pendampingan dan peran serta masyarakat dalam rangka mengobati trauma mereka.
\end{abstract}

Kata-kata kunci: 'comfort women', kolonisasi Jepang, media, kekerasan seksual, gerakan sosial 


\section{Introduction}

The World War might ended, but the story remain. There was a story about ignored suffering and hope that being forgotten. This illustrates how's the live of the 'comfort women' survivors who were blamed and compared as sexual workers. They were excluded from society and their case was never revealed, not even with apologies. Japanese military occupation wasn't only sacrificing men who forced to work as Romusha. During the occupation, women were used as gratification media, forced to be 'comfort women', and being sexually harassed. Some facts say that 'comfort women' survivors are living in fear and pain. The sources of their fear are coming from themselves, because they afraid to declare their identity and forced to keep silent to avoid people's talk. They were seen as taboo.

The social movements is trying to break this silence. Korean Council for the Women Drafted for Military Sexual Slavery by Japan is a proof of their movement to sue their rights, for being acknowledged, and to receive apologies. Women from several countries are in the list, such as Indonesia, Philippines, China, and South Korea. South Korea believe that those social movements would be easy to reach and then they began to lead. With the help of local media, The Korean Council keep promoting and campaigning the return of self-dignity towards the victim of 'comfort women' in South Korea. The action that took place in South Korea, also happened in other ex-colonized countries, such Indonesia but with different tension. The main problem is the way society looks into the survivors, which is considered as taboo and improper to be discovered. This way of thinking still remains in many places. The role of media is first to help shifting people's paradigm, so survivors can take an advance progress to bravely declare about who they were in the past. And even starts the movement to take back their rights, be acknowledged, and get proper apologies.

The history says that women in Japanese War era were recruited and mobilized to many places. Korean girls were even transferred to Semarang, Indonesia and were placed in brothels. They didn't get paid and were tortured if they denied to serve the costumer. Some of them also got shot and killed if they tried to fight the soldiers. The good thing is today's talk does not merely reveal how cruel the Japanese at that time. People doesn't need hate speech no more. But more notice on how people share empathy and support the efforts to give the rights back to the survivors. Modern people no longer see them as 'bad girl'. Media is claimed as the right partner to send the message to public to reset people's mind about 'comfort women'. From the view of social movers, the fundamental factor that defines the success of this movement is mobile resources. According to Gamson (1989), mobilization is a process of increasing the readiness to act collectively. The same feeling of being victimized may become source for those people 
to come to the stage and speak out. The position of media then led those voices and broadened their protest to the surface. Nevertheless, this such of mobilization required complex factors. However, several examples of social movements which led people to protest might give motivation to any struggle for justice. With different places and purposes, those movements can illustrate any process of collective action, for examples are the struggle against apartheid in South Africa (Marx 1992), The Nicaraguan women's movement (Isbester 2001) which is a form of women and minority organizations mobilization on national scale(Minkoff 1995),. These examples show shifted perspective on how mass mobilization can trigger collective actions. Social group accommodate people with similar experience to fight for common purposes. Collective group that almost always have different concern, are collected and gathered to encourage the same vision. Each group might stand for different points or located in different places and regions. But still, the social movements do exist with distributing bundles of recourses, gathering people from various background and even races.

Furthermore, Snow and Soule (2004) emphasizing social movements as a principal social forms where people can give their voice about grievances or concern about rights, welfare, well-being, and others. They do it by engaging on many collective actions, like protesting in the streets to show grievances, to demand something to be done or be fixed. This essay is trying to explain that massive actions are needed to change some policies or paradigm. That struggle is preferably done by collective efforts and persistency. However, these efforts are now shifted to public to be seen by as much as it can. Meyer and Tarrow (1998) wrote that today we are living in a 'movement society' that persuade worldwide society to engaged, gives empathy, or feels the same sadness. Hopefully, those massive opinions lead its way to government's attention, resulting for resolution. Somehow, it continues to intense negotiation and focus on discussion until decision finally made by leaders. The idea of social movement also aimed to collect tangible and intangible resources. Tangible sources are obtained from individuals and materials, such as money and funding or attributes needed in protest. But, the movement may leads to intangible things like a same vision, cultures, politics, and power or networks.

Many forms of social movements of course need a tool to perpetuate their action and persuading more people to at least feel what they felt. That role goes to the media that acts as everyone's friend. However, almost everybody can freely access the media in both printed and electric form. Along with the increasing of people's literacy, media raise its existence. Media somehow influences people's way of thinking. The objective of media as the method to mobilize society cannot be replaced by any means. The way media provides news and updates have been effectively 
proven to persuade, driving opinions, and mobilize people power. Every individual today is able to express anything in social media, even without any significant barriers. This chance leads media to be the most effective way on collecting people. But remember, not all media will be proper enough on assisting people's struggle because some of them are not neutral. Everything is based on party interests, so does media. It left us some tasks to find the most suitable platform of media in order to not shift the opinion entirely, because it may drives people to an ambiguous state that leads to people's confusions. Mass media also can take position as mediator and provide audience.

Media stands as a tool of communication between the interests owner and society as the audience. Gitlin (1980) mentioned that media took its part to select, mould, comment, evaluate allies or oppose them during the conflict. It also means that media can contribute to propose the struggle, endorse and bridge protests. But in another way, media can contrary accommodating any comments cons to the struggle. Furthermore, media's audience can't just contain of homogenous society. They divided into several segments, so their feedback may vary. One of that segments is those who take neutral position to the rising issues. This group have a very little interest or not dealing with those issues. The other group is divided into pro's and con's, whose comments and feedbacks can be very extreme sometimes. The pro's group usually have reasonably reason to voluntarily join the movement, so they tend to fight for their interest on related issue.

\section{The power of social movement in 'comfort women' in Korea}

Since 1990, South Korea is one of the remarkable country who has strong commitment in order to struggle of justice for 'comfort women'. Despite of political background between South Korea and Japan, the 'comfort women' issue became a concern which mostly led by the grassroot movements. At that time, a coalition from 37 women and human rights organizations and individuals has established the Korean Council for the Women Drafted for Military Sexual Slavery by Japan.

The Korean Council is one of the prominent organization that actively organizing the massive social movement in South Korea to support "comfort women" survivors. One year later, they succeed to ensure the first survivor, Ms. KIM Hak-Soon to came forward in public to give her testimony (Tanaka, 2002). This achievement was triggering the public attention, both from South Korean government and Japan. In 1992, when Prime Minister of Japan was visiting South Korea, the Korean Council conducted the protest to express the 'comfort women' voices (Shin, 2016). The first demonstration is called 'Wednesday Demonstration', because they always arrange their event on every Wednesday at 12:00 noon in front of Japanese Embassy until nowadays. 
Wednesday Demonstration always attended by some 'comfort women' survivors, people call them halmonies or grandma. In front of hundreds of peoples, they gave their orations to tell about the suffering from being sex slavery by Japan. Mostly, they were trapped behind the shadow 'recruitment' that took them to the nightmare of their life. Many 'comfort women' admitted that they were recruited with several reason for occupations. Kimura (2016) mentioned that: “In Korea, many women were recruited to work in restaurants, factories or hospitals. Who's actually offered these jobs and to what extent the women could refuse the offer varied" (p.128). The narrative testimony from survivors is the basic source to get strong evidences in order to condemn Japan. However, bring survivors to come forward isn't an easy task. The sensitiveness of 'comfort women' issue itself were pressing victims into their lowest emotional conditions. The presence of social movement activists is playing the key role in order to convince and encourage survivors to accept and speak up their voices.

This is the challenge that makes social movement of 'comfort women' issue in Korea looks interesting. They proved that their movement could mobilize people resources to gain their goals. The real goal of this movement is to change the improper system (Melucci, 1996) hiding the truth of 'comfort women'. They're trying to collect supports, makes them as their resources, and mobilize them intensely to build new system. The just system is what they aim to return the rights, dignity and reputation of 'comfort women' survivors. Although they began the movement with small resources, they proven to expand it to be wider movement as seen now, when thousands of people gather on Wednesday Demonstration in solidarity to support 'comfort women'.

Another lesson that we might be able to capture from social movement in Korea for 'comfort women' is the way they organized this movements. Many young generations involved in the movement, especially when they conduct Wednesday demonstration. This is a unique and effective ways to internalize and regenerate their understanding about the history of 'comfort women', because it is very important to avoid 'comfort women's' position of being denied by false construction of history. The truth must be told to young generation as future agents to spread out the mission in the sense of how worst the effect of war. That is why the Korean Council as leading organization in 'comfort women' issue in Korea is very welcome to accept the involvement of young generation.

'Comfort movement' not only fight for their own rights, they also focus on the mission of creating gender wise in post war policy. They promote to recognize the position of women and the rights of victims. The Korean Council believe that adopting gender wise perspective could generate the ideal solution for war's victim in post-war area. They took action to help 
other women in war-affected area through "butterfly funding". They share the experience and fund to reduce the impact of war against women and children.

On behalf of 'comfort women' rights and justice, the Korean Council demanding seventh requirements to Japan. First is for the acknowledgement of military sexual slavery crime, this is the important basic thing to get law enforcement into Japan. Second is disclosure of the full truth, because it is very urgent to make all 'comfort women' to get their dignity back. Third is official apologies to the victims, it is a requirement to makes it official to get legal and clear recognition for the 'comfort women', both in the local and global context. Fourth is legal reparation for victims over financial, physical, mental, and health needs. Fifth is punishment for those who responsible for creating deterrent effects and to avoid any possibilities of similar action in the future.Sixth is to correct the depictions in history books, this is also really important in order to give true story for future generation. Seventh is the construction of memorial monuments to simbolyze strong urge to commemorate the suffering of 'comfort women' and reminds all people about how worst the war impacted to women (Shin, 2016). However, those demands are not easy to get, that is why the Korean Council need supports from various parties.

\section{The role of Korean media in 'comfort women' issue}

Achieving those seven demands are not the final goal.It must be realized that is the least action to cure the past pain. It must be recognized as the most rational way which can dissociate the survivors for more suffer and loss. Even if the whole demands has been achieved with plenary, yet no guarantee that the survivors are finally cured. By re-opening the case, the survivors need to struggle once more, and even harder. How can it be? By make it public, the survivor have to declare their identity as the ex of 'comfort women', which can return them into bitter memories in past. Asians are inevitably still seeing no difference between the 'comfort women' and sexual workers. People somehow negate the fact that most of 'comfort women' in Japan regime were kidnapped and tricked, so they were not voluntarily involved. If the paradigm does not change, the prudency is then should be borne by family members. First thing first, it takes guts and mental strength from the survivors to be able to witness and help revealing the buried case.

This is justifying the roles of media that doubled as the " $x$ " factor. Because whoever controls media, can controls people's mind. Media should stand as a pioneer to bring awareness and knowledge for society to understand that the comfort women cannot be blamed as sexual workers. Regarding the role of media in order to set public attention, Merritt and 
McCombs argued that: "the power of the news media to set the nation's agenda, to focus public attention on a few key public issues, is an immense and well-documented influence" (Merritt and Combs 2014:41). Public musts know that it is certainly beyond discussion about whether sexual working of 'comfort women' is a commendable job or not. The main consideration is finally to give secured feeling to the survivors as well as a guarantee that she will not being marginalized by society, again. The second role, media have to lead public opinion to convince that what Japan's military did in past was wrong, then urge the government suing the seven demands.

What happened in South Korea was the best among the 'comfort women' problem solving than the others. The others are the victim of the 'comfort women' who are widespread in several countries in Asia, such as China, Philippines, and of course Indonesia. South Korea has proven that is possible to create such a move, in order to reveal truth and seek the best for the victims of 'comfort women'. However, the role of media is shown significantly in massive broadcasting, sending images and messages to public. For example, contributor Michelle Chenfor, Al-Jazeera news (January, 2016) reported that the latest agreement between Korea and Japan just reopens the old wounds, since the new deal that they made is yet represent the voice and demand of the survivors. This case proved that support from media is playing their role to support the interests and positions of 'comfort women'.

Furthermore, media attendance and enthusiasm at Wednesday demonstration indicating them as an agent to spread out update information about 'comfort women'. One evidence from a collaborative works of journalist Hilde Janssen and photographer Jan Banning (October, 2015) were showing around 50 pictures of 'comfort women' survivors. This action intends to recognize and remind their stories. This exhibition has already been conducted at several places in Japan, Indonesia, Netherlands, United States, Germany, France and Indonesia.

Final but not least, the hopes are granted. Japan was establishing the landmark for showing apologies for the issue of 'comfort women'. In 2014, Japan gave compensation, but it was rejected because it was funded by private. Achieving the seven demands is still a long way to go, but it is enough to show that non-stop efforts and consistence will give significant result.

\section{Conclusion}

Changing the history is somehow impossible to do, and somewhat is not important to do. Finding the reality that women in past decade were harassed and abused, boosts the movement of people in hope to find resolution and curing the pain. Most people's mind still filled with thought 
that women related to any sexual works will be blamed and rejected by society. But the paradigm is something changeable, it can change along the time and with consistent efforts. South Korea proves how that paradigm had shifted. The seven demands sued by Korean Council for the Women Drafted for Military Sexual Slavery by Japan slowly began to realize.

Media does not stand to provoke people or sending hatred about Japan's colonization. Media stands as the bridge between all parties. By the help of media, people get wider understanding about what had happened in the past, especially how the survivor of 'comfort women' had lived in fear and insecurity. This is a kind of goal for the media in achieving global understanding. Media can be miss-used for sure, that is why we have to keep watching and supervising. In the case of 'comfort women', media contribute on so many progresses. One of the results, Japan is finding its way to send an official apologies to the survivors. However, this perks is supposed to be adopted in any other countries, such Indonesia. Women organization can initiate the path; cooperate with media and government to give the rights of the survivors and get their dignity back.

\section{References}

Aljazeera (2016). Comfort Women' Shunted For Geopolitical Gain [online]. Aljazeera. Available at: <http://america.aljazeera.com/ opinions/2016/1/comfort-women-shunted-for-geopolitical-gain. html.> [accessed on Janua ry 5, 2016].

Davis, M. and McCombs, M. (2004). The Two Ways of Journalism: the Why and What of Public Affairs Journalism. London: Lawrence Erlbaum Associates Publishe rs.

Gamson, W.A. (1989). The Strategy of Social Protest. London: Chapman \& Hall.

Gitlin, T. (1980). The Whole World is Watching: Mass Media and the New Left, 1965-70. Berkeley: University of California Pr ess.

Isbester, K. (2001). Still Fighting: the Nicaraguan Womens Movement, 19772000. Pittsburgh: University of Pittsburgh Press.

Japan Times (2015). Photo Exhibition Shows Pain of Indonesian Former 'Comfort women' [online]. Japan Times. Available at: <http://www. japantimes.co.jp/culture/2015/10/19/arts/photo-exhibition-showspain-indonesian-former-comfort-women/> [accessed on Octobe $\mathrm{r}$ 19, 2015].

Kimura, M. (2016). Unfoldingthe 'Comfort Women' Debates: Modernity, Violence, Women's Voices. UK: University College Lond on.

Marx, A.W. (1992). Lessons of Struggle: South African Internal Opposition: 1960-1990. New York: Oxford University Press. 
Melucci, A. (1996). Challenging Codes: Collective Action in the Information Age. Melbourne: Cambridge University Press.

Meyer, D.S., and Tarrow, S.G. (1998). The Social Movement Society: Contentious Politics for a New Century. Lanham: Rowman \& Littlefield.

Minkoff, D.C. (1995).Organizing for Equality: the Evolution of Women's and Racialethnic Organizations in America, 1955-1985. Rutgers University Press: New Brunswick, New Jersey.

Shin, H. (2016). From Local to Global: Using International Human Rights Mechanism- the Case of 'Comfort Women'. Paper presented at the 9th Ewha Global Empowerment Program.

Sow, D.A. and McAdam, D. (2010). Readings on Social Movements: Origins, Dynamics and Outcomes. New York: Oxford U Press

Snow, D.A., Soule, S.A. and Kriesi, H. (2004). The Blackwell Companion to Social Movements. Malden, MA: Blackwell P ub.

Tanaka, Y. (2002). Japan's 'Comfort Women': Sexual Slavery and Prostitution during World War II and the U.S. Occupation. London: Routl edge 